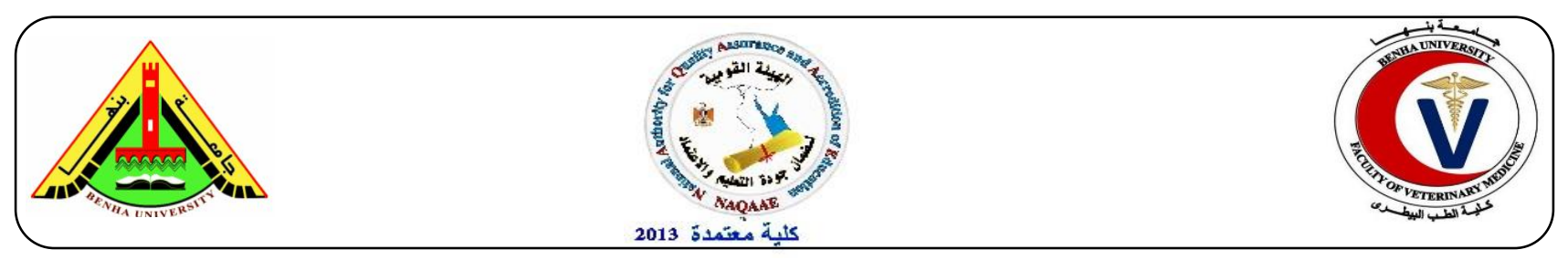

\title{
Chemical criteria of chicken meat
}

Faten S. Hassanin ${ }^{a}$; Mohamed, A. Hassan ${ }^{a}$; Fahim, A. Shaltout ${ }^{a}$, Nahla A. Shawqy ${ }^{b}$ and Ghada A. Abd-Elhameed.

${ }^{a}$ Food Control Dep., Fac. Vet. Med., Benha Univ.

\section{A B S T R A C T}

The chemical composition of each chicken cuts-up is greatly varied from one to another. A total of 50 random samples of chicken meat represented by breast and thigh ( 25 for each) were collected from local commercial retail shops at Menoufia governorate. Each sample weighting about $100 \mathrm{gm}$. The collected samples were tested for their PH values, TVN, TBA and Peroxide value. The results show that the maximum values of $\mathrm{pH}$ in the examined chicken breast and thigh samples ranged from 5.7 to 5.96 and 5.65 to 5.84 , respectively with mean values of $5.81 \pm 0.05$ and $5.73 \pm 0.03$, respectively. TVN value in the examined samples of chicken carcasses was ranged from 2.3 to 8.5 with an average of $5.56 \pm 0.24 \mathrm{mg} \%$ for breast and 3.8 to 10.9 with an average of $7.12 \pm 0.29 \mathrm{mg} \%$ for thigh. TBA values $(\mathrm{mg} \%)$ of the examined samples of chicken breast and thigh were ranged from 0.06 to 0.14 and 0.08 to $0.21 \mathrm{mg} \%$, respectively with mean values of $0.09 \pm 0.01$ and $0.14 \pm$ 0.01 , respectively. The peroxide values in the examined samples of chicken carcasses were varied from 0.11 to 0.26 with a mean value of $0.19 \pm 0.01$ for breast and 0.14 to 0.39 with a mean value of $0.27 \pm 0.01$ for thigh. From the previous results it could be concluded that chicken meat from local commercial retail shops in Menoufia governorate were acceptable based on their $\mathrm{pH}$ values, TVN, TBA and Peroxide value as all samples were nearly within their permissible limits.

Key words: Breast, thigh, PH, TBA, Peroxide value.

(http://www.bvmj.bu.edu.eg)

(BVMJ-33(2): 457-464, 2017)

\section{INTRODUCTION}

In Egypt, chicken occupy the major role in production and consumption among poultry. Chickens appear more frequently than any other food animals, so acts as a main source of protein in the diet of the people throughout the world. Chicken meat becomes the second most popular meat eaten after red meat. Chicken meat is characterized by ease during preparation, consistent quality and the availability of the wide range of pre-packed, branded, raw and ready to eat and serve products (shedeed, 1999). Meat from chicken is usually used because of the high chicken meat yield, low shrinkage during cooking, ease of cooking and serving and of low cost (Branscheid, 1993).

The chemical composition of each chicken cuts-up is greatly varied from one to another (Lawrie, 1998).

The meat with a pH below 5.8 had a 
pale color, while in meat with $\mathrm{pH}$ higher, the color was too dark and it has a great risk on human health. So the ideal $\mathrm{pH}$ for meat is between 5.8 and 6.3 (Pearson and Gillette, 1996). The decrease in $\mathrm{pH}$ value in meat may be attributed to the breakdown of glycogen with the formation of lactic acid and the increase of $\mathrm{pH}$ may be due to the partial proteolysis leading to the increase of free alkaline groups depending on the condition of such changes. Besides, higher $\mathrm{pH}$ values of leg meat compared to breast meat could be due to the increase of lactic acid concentration via anaerobic metabolism in breast meat (Jay, 1972).

Accordingly, Total Volatile Nitrogen (TVN) can be considered as a reliable indicative measure for the quality of various food articles specially meat and meat products. In general, TVN in meat products may be increased as the days of storage increased where protein break down (ammonia) may occur due to microbial growth and its proteolytic enzymes (Alina and Ovidiu 2007).

Thiobarbituric acid (TBA) test has been widely used for measuring oxidative rancidity in fat containing food. The TBA test is a sensitive test for determination of the decomposition of products of highly unsaturated fatty acids (Melton, 1983).

Oxidative deterioration results in losing the quality of chicken cuts-up due to development of rancid odor and taste. Moreover, the rancid flavor can develop rapidly during refrigerated or frozen storage of chicken cuts-up which are more susceptible to rancidity because of their high contents of unsaturated fatty acids (Ang, 1988).

The peroxide formation accelerates formation of other peroxides in a propagation step. Peroxides are referred to as "free radicals" and there has been much emphasis in the press and from the health industry on preventing free radicals. "Free radicals" or peroxides will destroy the normal state of many chemicals in our bodies, in food products, and other biological matter. In food, the presence of peroxides will immediately alter the taste (Chekani-Azar et al., 2009).

Therefore, the present study was planned out to determine $\mathrm{pH}$, total volatile nitrogen (TVN), thiobarbituric acid number (TBA) and peroxide value (PV) in breast and thigh.

\section{Materials and methods}

\section{2.-Collection of samples :}

A grand total of 50 random samples of chicken carcasses (breast and thigh) represented by 25 samples of each were collected from local commercial retail shops at Menoufia governorates. Each sample weighting about $100 \mathrm{gm}$. The collected samples were aseptically transferred, without undue delay, in an insulated ice box to the laboratory and then were subjected to the following examinations.

\section{2._Determination of $\mathrm{pH}$ :}

It carried according to (Pearson, 2006)

\subsection{Determination of Total Volatile Nitrogen} $(T V N)$ :

The technique applied for determination of total volatile nitrogen (TVN) was recommended by Food and Agriculture Organization "FAO" (1980)

\subsection{Determination of Thiobarbituric Acid Number (TBA):}

The method adopted for estimation of TBA by Pikul et al. (1989) was applied

\subsection{Determination of peroxide value:}

It was carried according to Asakawa and Matsushita (1978).

6.2. Statistical Analysis: All data were 
subjected to statistical analysis according to the procedures reported by Snedecor and Cochran (1980).

\section{RESULTS}

Results achieved in table (1) indicated that the minimum and the maximum values of $\mathrm{pH}$ in the examined chicken breast and thigh samples ranged from 5.7 to 5.96 and 5.65 to 5.84 , respectively, with mean values of $5.81 \pm$ 0.05 and $5.73 \pm 0.03$, respectively.

The data recorded in table (2) indicated that TVN value in the examined samples of chicken carcasses was ranged from 2.3 to 8.5 with an average of $5.56 \pm 0.24$ $\mathrm{mg} \%$ for breast and 3.8 to 10.9 with an average of $7.12 \pm 0.29 \mathrm{mg} \%$ for thigh.

According to Egyptian Organization for Standardization (E.O.S, 2005) for poultry meat, all the examined samples were within the accepted level as TVN were lower than 20 $\mathrm{mg} \%$ as shown in table (3).

The achieved data in table (4) Showed that the minimum and maximum of TBA values $(\mathrm{mg} \%)$ of the examined samples of chicken breast and thigh were ranged from 0.06 to 0.14 and 0.08 to $0.21 \mathrm{mg} \%$, respectively with mean values of $0.09 \pm 0.01$ and $0.14 \pm 0.01$, respectively.

In table (5) According to Egyptian Organization for Standardization (E.O.S, 2005) for poultry meat, all the examined samples were within the accepted level as TBA were lower than $0.90 \mathrm{mg} / \mathrm{Kg}$.

Table (6) indicated that the peroxide values in the examined samples of chicken carcasses were varied from 0.11 to 0.26 with a mean value of $0.19 \pm 0.01$ for breast and 0.14 to 0.39 with a mean value of $0.27 \pm 0.01$ for thigh.

\section{DISCUSSION}

The chemical and nutritional composition of poultry meat is greatly varied from one species to another (Lawrie, 1998).

Chickens appear more frequently than any other food animals, so acts as a main source of protein in the diet of the people throughout the world. Meat from chicken is usually used for infants, young children, aged and convalescents. Chicken meat can be sold as a raw state or in ready to cook form. So, they may be sold as a whole carcass, quarted or disjointed, because of the high chicken meat yield, low shrinkage during cooking, ease of cooking and serving and of low cost (Branscheid, 1993).

Concerning the $\mathrm{PH}$, according to results achieved in table (1), comparing the obtained values from the examined samples of chicken breast, the values were nearly similar, to some extent to, Ristic and Schorn (1977) ( 5.86), Dianek et al., (1989) (5.8) ,Fathi-Eman(2012)( 5.8 to 6.1) and Noha (2017) 5.78+5.94.

The higher results were achieved by Shedeed (1999) (6.10) and Afifi-Jehan (2000) (6.15).

Furthermore, for the examined chicken thigh the nearly similar records were reported by Shedeed (1999) (5.70), Noha (2017) 5. 68 \pm 5.83 and Fathi-Eman(2012)( 5.6 to 5.9).

The higher results were obtained by Ristic and Schon (1977) (6.44); Dianek et al., (1989) (6.6), Hassanine- Fatin and Hassan (2003) $(6.57 \pm 0.03)$ and Afifi-Jehan (2000) $(6.21 \pm 0.034)$.

Finally, for the examined chicken thigh samples, the values were lower than that obtained by Hassanine - Fatin and Hassan (2003) $(6.67 \pm 0.02)$. 
Table (1): Statistical analytical results of $\mathrm{pH}$ values in the examined samples of chicken carcasses

\begin{tabular}{lccc}
\multicolumn{1}{c}{$(\mathrm{n}=25)}$. & Min & Max & \\
\hline Chicken tissues & & & \\
& & & \\
\hline Breast & 5.70 & 5.96 & $5.81 \pm 0.05$ \\
Thigh & 5.65 & 5.84 & $5.73 \pm 0.03$ \\
\hline
\end{tabular}

S.E $E^{*}=$ Standard error of mean

Table (2): Statistical analytical results of Total Volatile Nitrogen "TVN" (mg \%) in the examined samples of chicken carcasses $(n=25)$.

\begin{tabular}{lccc}
\hline Chicken tissues & Min & Max & Mean \pm S.E \\
& & & \\
\hline Breast & 2.3 & 8.5 & $5.56 \pm 0.24$ \\
Thigh & 3.8 & 10.9 & $7.12 \pm 0.29$ \\
\hline
\end{tabular}

S.E ${ }^{*}=$ Standard error of mean

Table (3): Acceptability of the examined samples of chicken carcasses based on their levels of TVN (n=25).

\begin{tabular}{ccccc}
\hline & & \multicolumn{2}{c}{ Accepted } & \multicolumn{2}{c}{ Unaccepted Samples } \\
Poultry species & $\begin{array}{c}\text { Maximum Permissible } \\
\text { Limit }(\mathrm{mg} \%)^{*}\end{array}$ & \multicolumn{2}{c}{ Samples } & \\
\cline { 3 - 5 } & 20 & No. & $\%$ & No. \\
\hline Breast & 25 & 100 & 0 & 0 \\
Thigh & 25 & 100 & 0 & 0 \\
\hline
\end{tabular}

* Maximum Residual Limit stipulated by Egyptian Organization for Standardization "EOS" (2005). 
Table (4): Statistical analytical results of Thiobarbituric acid (TBA) "mg/Kg" in the examined samples of chicken carcasses $(n=25)$.

Chicken tissues Min Max Mean \pm S.E*

\begin{tabular}{llll}
\hline Breast & 0.06 & 0.14 & $0.09 \pm 0.01$ \\
Thigh & 0.08 & 0.21 & $0.14 \pm 0.01$ \\
\hline
\end{tabular}

S.E ${ }^{*}=$ Standard error of mean

Table (5): Acceptability of the examined samples of chicken carcasses based on their levels of TBA $(n=25)$.

\begin{tabular}{cccccc}
\hline & & \multicolumn{2}{c}{ Accepted } & \multicolumn{2}{c}{ Unaccepted Samples } \\
Poultry species & $\begin{array}{c}\text { Maximum Permissible } \\
\text { Limit }(\mathrm{mg} / \mathrm{Kg})^{*}\end{array}$ & \multicolumn{2}{c}{ Samples } & \\
\cline { 3 - 5 } & & No. & $\%$ & No. & $\%$ \\
\hline Breast & 25 & 100 & 0 & 0 \\
Thigh & 0.90 & 25 & 100 & 0 & 0 \\
\hline
\end{tabular}

* Maximum Residual Limit stipulated by Egyptian Organization for Standardization "EOS" (2005).

Table (6): Statistical analytical results of Peroxide value (PV) "meqO2/kg" in the examined samples of chicken carcasses $(n=25)$.

\begin{tabular}{llll}
\hline \multicolumn{1}{c}{ Chicken tissues } & Min & Max & Mean \pm S.E \\
& & & \\
\hline Breast & 0.11 & 0.26 & $0.19 \pm 0.01$ \\
Thigh & 0.14 & 0.39 & $0.27 \pm 0.01$ \\
\hline$E^{*}=$ Standard error of mean & & &
\end{tabular}

S.E $E^{*}=$ Standard error of mean

The decrease in $\mathrm{pH}$ value in meat may be attributed to the breakdown of glycogen with the formation of lactic acid and the increase of
$\mathrm{pH}$ may be due to the patial proteolysis leading to the increase of free alkaline groups depending on the condition of such changes 
(Jay, 1972).

Concerning TVN, according to the results recorded in table (2) for chicken breast, they are relatively agree, to same extent, with those obtained by Rossadkina (1978) (3.53mg\%) and Noha, M.A.(2017) $2.26 \pm 7.82$

Higher results were recorded by Afifi

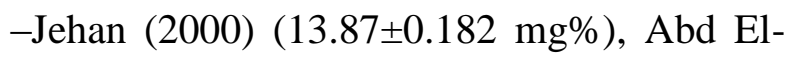
Wahed (1986) (11.06 mg\%), Abd El-Baki et al., (1983) (9.37 mg\%) and Fathi (2012)( 5.6 to 5.9).

Concerning the examined samples of chicken thigh, they are nearly similar to those reported by Abd El-Wahed (1986) (10.16 mg\%), Abd El-Baki etal., (1983) (8.23 mg\%), Noha, M.A.(2017) 3.06 \pm 9.57 and FathiEman(2012)( 4.1 to 10.3), while higher results were achieved by Hasanine and Hassan (2003) (30.76 \pm 1.07) and Afifi (2000) $(12.57 \pm 0.222 \mathrm{mg} \%)$.

Ammonia is the most spoilage present in spoiled meat and meat products which is directly responsible for spoilage odors and flavors as ammonia, it is an indicator product of amino acid degredated by bacteria and it can be measured as total volatile basic nitrogen (Gill, 1983).

Accordingly, TVN can be considered as a reliable indicative measure for the quality of various food articles specially meat and meat products. In general, TVN in meat products may be increased as the days of storage increased (Reddy etal., 1970).

According to table (3) Egyptian Organization for Standardization (E.O.S, 2005) for poultry meat, all the examined samples were within the accepted level as TVN were lower than $20 \mathrm{mg} \%$.

Concerning TBA, according to table (4) the examined chicken breast muscle results nearly similar to results were recorded by Afifi (2000) (0.119 \pm 0.007$)$, Noha, M.A.(2017) 0.03 \pm 0.11 and Fathi (2012)( 0.02 to 0.06). Higher results were obtained by Moawad (1987) (0.31 mg\%), Shams El-Din and Ibrahim (1990) (0.58 \pm 0.12$)$ and Shedeed (1999) ranged from (0.28 to $1.69 \mathrm{mg} \%)$.

For the examined chicken thigh samples, nearly similar records were obtained by Afifi

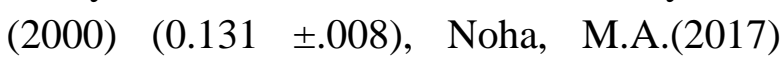
$0.04 \pm 0.15$ and Fathi-Eman(2012)(0.05 to $0.12)$. The obtained results were lower than that recorded by Moawad (1987) (0.51 mg\%) ; Shams El-Din and Ibrahim (1990) (0.81 \pm $0.15)$; Shedeed (1999) ranged from (0.36 to $2.47 \mathrm{mg} \%$ ) and Hassanine and Hassan (2003) $(0.352 \pm 0.015)$.

The oxidative rancidity in fresh, frozen and cooked chicken breast and leg meat was evaluated by measuring malonaldehyde in fat meat with an improved thiobarbituric acid (TBA) assay with antioxidant protection ( Abd El-Kader, 1996).

In table (5) According to Egyptian Organization for Standardization (E.O.S, 2005) for poultry meat, all the examined samples were within the accepted level as TBA were lower than $0.90 \mathrm{mg} / \mathrm{Kg}$.

According to table (6), indicated that the peroxide values in the examined samples of chicken carcasses were varied from 0.11 to 0.26 with a mean value of $0.19 \pm 0.01$ for breast and 0.14 to 0.39 with a mean value of $0.27 \pm 0.01$ for thigh.

Once oxidation has run its course, the oxidized food article will have essentially changed, chemically different from its original form and potentially toxic, which is why it is considered rancid and unusable (Amato et al., 1989).

The presence of unsaturated fatty acids in the food articles increases their 
nutritive value and decrease the shelf-life of the product. Also, the high percent of saturated fatty acids of the product decrease the nutritional value and increase the shelflife of the product (Pearson, 1984).

\section{CONCLUSION}

Poultry meat provide to be an excellent food article prepared and considered as a good supplement of animal protein for a deficient diet and consumption of chicken meat has increased therefore the goals of this study were to evaluate the chemical quality of chicken meat. From the results it could concluded that chicken meat from local commercial retail shops were acceptable based on their PH values, TVN, TBA and Peroxide value as all samples were nearly within their permissible limits.

\section{REFERENCES}

Abd El-Baki, M. M.; Taha, R. A.; El-Zayet, F. M. M.; El-Dashlouty, A. A. and Fouda, Z. M. A (1983):Influence of some pre-freezing treatments on the chemical and physical properties of chicken meat. Proc. $29^{\text {th }}$ Euro. Meeting of Meat Res. Workers, Parma, 464.

Abd El-Kader, Z. M. (1996):Lipid oxidation in chicken as affected by cooking and frozen storage. Nahrung, 40(1):21-42.

Abd El-Wahed, W.Z.M. (1986):Effect of preparation and cooking method and characteristics of poultry meat. Ph. D. Thesis, Faculty of Agric, Cairo University.

Afif, Jehan, S.A. (2000):Chemical studies on some poultry meat products. M.V.Sci. Thesis, Fac. Vet. Med. Zagazig Univ.

Alina, $\mathrm{H}$. and Ovidiu T. (2007):Determination of total protein in some meat products. Analele Stiintifice ale Universitatii, Alexandru Ioan Cuza,
Sectiunea Genetica si Biologie Moleculara,TOM VIII.

Amato, P. M.; Hamann, D. D.; Ball, H. R. and Foegeding, E. A. (1989):Influence of poultry species, muscle groups and Nacl level on strength, deformability and water retention in heat-Set muscle gels. J. Food Sci., 54(5):1136-1140.

Ang, C. Y. (1988):Comparison of broiler tissues for oxidative changes after cooking and refrigeration storage. J.Food Sci., (53):1072-1075.

Asakawa, S. and Matsushita, T. (1978): Colorimetric determination of peroxide value with potassium iodide-silica gel reagent. J. American Oil Chemists Society, 55 (8): 619-620.

Branscheid,W.(1993):Consumer expectation on the quality of foods of animal origin. Kongress Band 1993 Hamburg. Vortage Zum Generlthema des 105. VDLUFAKongress vom 20-25. 9. 1993. In Hamburg: Qualitat and Hyriene von Leben- smitteln in production and Verabeitung., 23-32.

Chekani-Azar, S.; Farhoomand, P.; and Shahryar, H. A. (2009):Dietary fat type alter performance and quality of meat in broiler. WPSA., 2nd Mediterranean Summit of WPSA, Antalya, Turkey, 4(7):539-543.

Churchill Livingstone, Edinburgh, London, United Kingdom.

Dianek, W., Dransfield, E., Down, N. F. and Taylor, A. A. (1989):Influence of postmortem treatment on turkey and chicken meat texture. International Journal of Food Science and Technology, (24):81-92.

Egyption Organization for Standardization and Quality Contro "E.O.S" (2005): Detection of poisons and control. Report No .1796.

Fathy, Eman A.R. (2012): Chemical studies of chicken meat with Relation to its quality. Ph.D. Thesis, Fac. Vet. Med. Benha Univ. 
Food and Agriculture Organization "FAO"(1980):Manual of Food Quality Control. FAO, United Nation, Rome, Italy.

Gill, C.O. (1983):Meat spoilage and evaluation of potential storage life of fresh meat. J. Food Prot., 46(5), 444452.

Hassanine, Fatin, S. and Hassan, M. A. (2003):Chemical indices of incipient deterioration in chicken cut-up products. Benha- V.M.J, 14 (2):54-65.

Jay, J. M. (1972): Mechanism and detection of microbial spoilage in meats at low temperature- A status report. J. Milk Food Technol., (35):467-470.

Lawrie, A. R. (1998):Lawrie's meat science. $6^{\text {th }}$ Ed. Wood head Publishing Ltd.USA.

Melton, S. I. (1983): Methodology for following lipid oxidation in muscle foods. Food Technol., 37 (7):105-1116.

Moawad. R. K. (1995): Effect of pretreatment on quality attributes and nutritive value of frozen beef and chicken meats. Ph. D. Thesis Faculty of Agric, Cairo University.

Noha, M.A.(2017): Effect of biogenic amines on the chemical quality of poultry meat products, m.v.sc., meat hygiene, fac.vet.med.benha univ.

Pearson, A. M. and Gillette, T. A. (1996):Processed meats. $3^{\text {rd }}$ Ed New York Albany, Bonn, Boston, London.

Pearson, D. (2006): Chemical Analysis of Foods. $11^{\text {th }}$ Ed, Publishing Co.,
Pearson, D.(1984):Chemical Analysis of Foods $8^{\text {th }}$ Ed, Publishing Co., Churchill Livingston, Edinburgh, London, UK.

Pikual, J.; Leszezynski, D. E and Kummerow, F. A. (1988):Improved determination of lipid oxidation in chicken breast and leg meat after frozen storage and cooking. Fleischwirtsch., (68):869- 872.

Reddy, S.; Ilenrickson, R. 1. and Olson, H. C. (1970):The influence of lactic acid culryres on ground beef quality Oklahoma Agri. Experiment station, Stillwater, Oklahoma. J. Food Sci., 35787.

Ristic, M. and Schon, L. (1977): Changes in the muscle $\mathrm{pH}$ of broilers in relation to the year of production. Archive Fur Gflugelkunde., (41):253-256.

Rossadkina, E. A. (1978): Changes in white muscle hens under influence of technological factors. J. Food Technol., (125):57-59.

Shams El-Din, M. H. A. and Ibrahim, H. M. (1990): Cooking effects on fat and fatty acids composition of chicken muscles. Die Nahurung, 34 (3):207- 212.

Shedeed, N. A. (1999): Evaluation of microwave cooking of chicken meat. $\mathrm{M}$. V.Sci. Thesis, Fac. of Agric, Cairo University.

Snedecor,G.W.and Cochran ,W.G.(1980): Statistical Methods, Oxford and J.B.H. Publishing Com. $6^{\text {th }}$ Ed. 